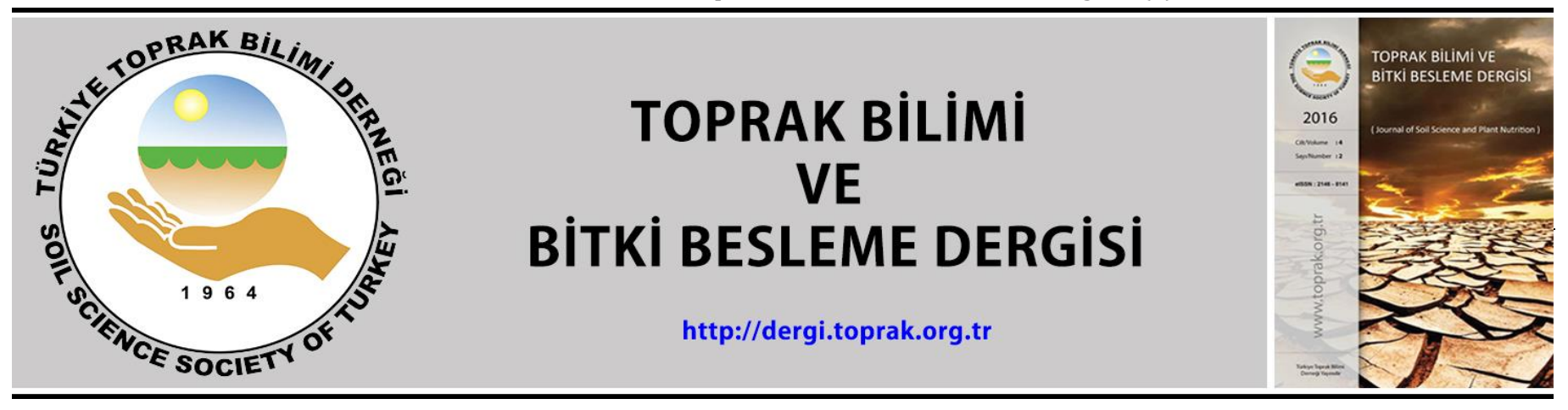

\title{
Afşin-Elbistan havzası linyit işletmesi organik materyallerinden geliştirilen organik ve organomineral gübrelerin buğday verimi ve verim bileşenleri ile bazı toprak özellikleri üzerine etkileri \#
}

\author{
Ayten Namlı *, Muhittin Onur Akça, Hanife Akça
}

Ankara Üniversitesi, Ziraat Fakültesi, Toprak Bilimi ve Bitki Besleme Bölümü, Ankara

\begin{abstract}
Özet
Bu çalışma kapsamında, Afşin Elbistan Linyit işletme sahasında mevcut içerikleri tanımlanmış organik materyallerden elde edilen organik toprak düzenleyicisi olarak humik asit ve bunların farklı oranlarda kimyasal gübrelerle kombinasyonuyla elde edilen organomineral gübrelerin buğday bitkisi ve toprak özellikleri üzerindeki etkinliklerinin belirlenmesi amacıyla, İç Anadolu Bölge koşullarını temsilen Ankara ili Haymana ilçesinde bir yıl süreli tarla denemesi kurulmuştur. Bu materyallerin toprağın bazı özelliklerine olan etkileri ve haymana denemesinde hasat parsellerinden tesadüfi 10 buğday bitkisi toplanarak boyları ölçülmüş, biçerdöver ile parseller hasat edilmiş ve dekara verim hesaplanmış, danede buğday kalitesinin göstergesi olan gluten, indeks, hektolitre, protein ve rutubet analizleri yapılmıștır. Organik materyal uygulaması bitki boyunu artırmıș, yanısıra yörenin geleneksel uygulaması olan tek bașına $20 \mathrm{~kg} \mathrm{da}^{-1}$ DAP uygulamasına kıyasla toprağa ilave edilen organik materyallerin tek başlarına ve kimyasal gübrelerle birlikte uygulanması buğday verimini de önemli düzeyde artırmıştır. Tüm uygulamaların kontrole göre toprağın $\mathrm{pH}$, organik madde ve değişebilir $\mathrm{K}$ değerini kontrole göre artırdığı $(\mathrm{p}<0.05)$ belirlenmiştir. Sonuç olarak incelenen özellikler birlikte değerlendirildiğinde; Afșin Elbistan Linyit işletme sahasında önemli miktarlarda bulunan organik materyallerin içerik analizlerinin yapılarak organik toprak düzenleyicisi, organomineral gübre, K-humat ve humik asit şeklinde değerlendirilmesinin buğday yetiştiriciliğinde önemli olduğu belirlenmiştir.
\end{abstract}

Anahtar Kelimeler: Organik toprak düzenleyici, humik asit, gidya, buğday, toprak.

Determination of the impacts of organic and organomineral fertilizers developed from the organic materials of Afşin-Elbistan basin lignite pit on the yield and yield components of wheat and on some soil characteristics

\begin{abstract}
In this study, a field experiment for a period of one year was built in Haymana County of the city of Ankara for Inner Anatolia Region representing the conditions of organomineral conditions obtained via the combination of humic acid, organic soil conditioners obtained from the organic materials with current contents defined at the site of Afşin- Elbistan Lignite and chemical fertilizer combinations at different rates. The effects of the applied materials on some properties of soil were determined. Besides, in the experiment of Haymana, coincident 10 plants were picked from the harvest plots, length of the spica were conducted, plots were harvested via plot combine harvester, gluten, index, hectoliter, protein and moisture analyses as indicators of wheat quality in grain were performed. Organic material application increased the plant height, as well as the application of organic materials added to the soil alone and with chemical fertilizers compared to the $20 \mathrm{~kg} \mathrm{da}^{-1}$ DAP application, which is the traditional application of the region, increased the wheat yield significantly. All of the applications increased in soil $\mathrm{pH}$, organic matter and exchangeable potassium in accordance with the control of applications $(\mathrm{p}<0.05)$. As a result considering the characteristics that were determined as a whole, it was determined that it was important for wheat growing to analyze the organic materials found in significant numbers in Afşin-Elbistan Lignite Pit as an organic soil conditioner by themselves through running content analyses, as organomineral fertilizer, K-humate, and humic acid.
\end{abstract}

Keywords: Organic soil conditioner, humic acid, gygja, wheat, soil.

(C) 2019 Türkiye Toprak Bilimi Derneği. Her Hakkı Saklıdır

\section{Giriş}

Tarım topraklarında geçmiş yıllardan beri devam eden konvansiyonel işlemeli tarım, her geçen gün değişen iklim özellikleri ve yanlış yapılan uygulamalar sonucunda organik madde kapsamı her geçen gün

\# Bu çalışma Elektrik Üretim A.Ş. (EUAŞ) tarafından desteklenmiştir.

* Sorumlu yazar:
Tel.
03125961758
Geliş Tarihi
26 Eylül 2018
E-posta : namli@ankara.edu.tr
Kabul Tarihi
11 Aralık 2018
e-ISSN
2146-8141
DOI : $10.33409 /$ tbbbd.594998 
azalmaktadır. Ülkemizin sahip olduğu doğal leonardit kaynaklarının değerlendirilmesi ile elde edilen hümik asitler toprakların verimliliğinin arttırılması ve sürdürülebilir bir biçimde yönetimi için katkı sağlayabilecek niteliktedir (Engin ve Cöcen, 2012).

Tarım yapılan topraklarda kullanılan organik toprak düzenleyicilerden bazıları leonardit, gidya ve linyit gibi organik materyallerdir. Bu toprak düzenleyicilerinin topraktaki etkileri içeriğinde bulunan hümik asitten ileri gelmektedir (Tamer ve ark., 2016). Bilindiği üzere humik asitlerin tarım yapılan topraklardaki etkileri sıralanacak olursa; toprakta geçirgen bir yapı oluşturup, toprağın yapısını iyileștirirler. Toprak reaksiyonu üzerinde olumlu etki sağlayıp, yüksek alkalinite sorunlarının önüne geçmede rol oynarlar. Topraktaki organik maddeyi arttırarak, bitki besin maddelerinin alınımını kolaylaştırırlar. Toprağa ilave edilen organik maddenin toprağın bazı fiziksel, kimyasal ve biyolojik özellikleri üzerine olumlu etkileri olduğu bilinmektedir (Shirani ve ark., 2002; Karaca ve ark., 2006; Tamer ve ark., 2016). Alagöz ve ark. (2006) organik madde ilavesinin toprağın bazı kimyasal ve fiziksel özellikleri üzerine etkisini inceledikleri araștırmalarında üç farklı dozda uygulanan ișlenmiş leonardit materyalinin toprakların $\mathrm{pH}$, organik madde ve toplam $\mathrm{N}$ içeriği üzerine arttırıcı etkisinin olduğunu belirtmişlerdir. Humik asit uygulamasının bitki gelişimi ve besin maddelerinin alımı üzerine etkileri birçok araştırmacı tarafından incelenmiştir (Sözüdogru ve ark., 1996; Günaydın, 1999; Kolsarıcı ve ark., 2005). Yılmaz ve Alagöz (2001) sıvı humik asit uygulamasının topraklarda agregat oluşum ve stabilitesi üzerine olan etkilerini araştırdıkları çalışmalarında kullanılan sıvı humik asit materyalinin \% 0.30 toplam N, \% 0.17 organik N, \% $0.41 \mathrm{CaO}, \% 15$ humik ve fulvik asit ve 6.5 pH'ya sahip olduğunu rapor etmişlerdir. Schnitzer ve Khan (1978) humik asit uygulanmasının bitki gelişimini doğrudan veya dolaylı olarak etkilediğini ve biyokütle miktarının önemli ölçüde arttığını belirlemişlerdir. Lobartini ve ark. (1997) humik asit ve mineral besin maddeleri uygulamalarının bitki kuru ağırlığına, bitki besin maddesi içeriğine ve bu besin maddelerinin bitki tarafından alınımına ve ayrıca tohum çimlenmesine olumlu etkilerinin olduğunu bildirmişlerdir. Erdal ve ark. (1999) yaptıkları bir çalışmada, humik asitin N, P, K gübreleri ile birlikte verilmesi ile elde edilen ürün artışının humik asitin tek başına verilmesinden elde edilen artıştan daha fazla olduğunu ve ayrıca humik asit uygulanmasının topraktaki $P$ yarayışlılığını arttırdığını belirtmişlerdir. Turgay ve ark. (2011) linyit kökenli humik maddelerin bazı toprak özellikleri ve ekmeklik buğday üzerine etkilerini saptamak amacıyla yaptıkları çalışmada; Adana ili Çukurova bölgesi 2005 ve 2007 yılları arasında, gidya ve gidyadan elde edilen humik-fulvik asit konsatrasyonunu toprağa hem tek başlarına hem de mineral bir gübre ile kombine halinde uygulayarak, iki yll tekrarlamalı olarak ekmeklik buğday yetiştirmișlerdir. Araștırma sonucunda; farklı tip ve dozlardaki humik maddelerin tek başlarına ya da kombine uygulamalarının, ardışık ürün sezonlarında toprak özelliklerindeki etkilerinin farklılık gösterdiğini belirlemişlerdir.

Türkiye linyit rezervinin en büyügü yaklaşık \% 46'lık bir oran ile Afşin-Elbistan Havzası olarak bilinmektedir. Bu havzada ekonomik işletilebilir linyit rezervi ise 3.2 milyar ton olarak belirlenmiştir (Koçak ve ark., 2001; Doğan, 2007). Bu araştırmada, Afşin Elbistan Linyit işletme sahasında mevcut içerikleri tanımlanmış organik materyallerden elde edilen humik asit, organik toprak düzenleyicisi ve bunların farklı oranlarda kimyasal gübrelerle kombinasyonuyla elde edilen organomineral gübrelerin, buğday verimi ve verim bileșenleri ile bazı toprak özellikleri üzerine etkileri tarla koşullarında değerlendirilmiştir.

\section{Materyal ve Yöntem}

Araştırma, tarla denemesi olarak Ankara ili Haymana ilçesindeki Ankara Üniversitesi Ziraat Fakültesi Uygulama ve Araştırma Çiftliği'nde tesadüf parselleri deneme desenine göre 4 tekerrürlü ve 13 uygulama konulu olarak bir ekim dönemi boyunca (Ekim 2015-Temmuz 2016) 2 dekar alanda yürütülmüştür. Yürütülen denemede parseller $4 \mathrm{~m}$ x $4 \mathrm{~m}$ boyutlarında hazırlanıp, bloklar arası ve parseller arasında 1,5 m boșluklar bırakılmıștır. Denemede test bitkisi olarak ekmeklik buğday (Triticum aestivum cv. Bezostaja) kullanılmıştır. Deneme alanından alınan toprak örneklerinin analiz sonuçlarına göre, temel gübrelerin ve organomineral gübrelerin uygulama dozları belirlenmiştir. Çalışmada kullanılan organomineral gübreler Namlı ve ark. tarafından EUAŞ Maden İşleri Dairesiyle birlikte yürütülen proje kapsamında elde edilmiştir. Uygulama konuları Çizelge 1'deki gibidir.

Nisan ayında üst gübreleme ve ilaçlama yapılmıştır. Ayrıca üst gübreleme esnasında organik materyal uygulanmış tüm parsellere $1 \mathrm{~kg} \mathrm{~K}$-humat $\mathrm{da}^{-1}$ uygulaması yapılmıştır. Ankara ilinin Haymana ilçesinde yürütülen tarla denemesi 13 Temmuz 2016 tarihinde deneme biçerdöver ile hasat edilmiştir. Verim kriterlerinin belirlenmesi amacıyla her parselden rastgele seçilerek etiketlenen 10 adet bitkinin ana saplarında toprak yüzeyinden başakta en üst başakçığın ucuna kadar olan uzunlukları (kılçılar hariç) ölçülerek bitki boyu $(\mathrm{cm})$ ve her parselde etiketlenmiş bitkilerin ana saplarına ait başaklardaki taneler 0.001 
g duyarlılıktaki terazide tartılarak belirlenmiştir. Buğday tanesinde buğdayın kalitesini ortaya koymaya yarayan protein, gluten, hektolitre, rutubet Kjeldahl yöntemiyle (Kacar ve İnal, 2008) belirlenmiștir. Hasat indeks $\mathrm{m}^{2}$ 'deki tane verimi esas alınarak kg da-1 olarak hesaplanmıştır (Yürür ve ark., 1981).

Çizelge 1. Denemede uygulanan konular

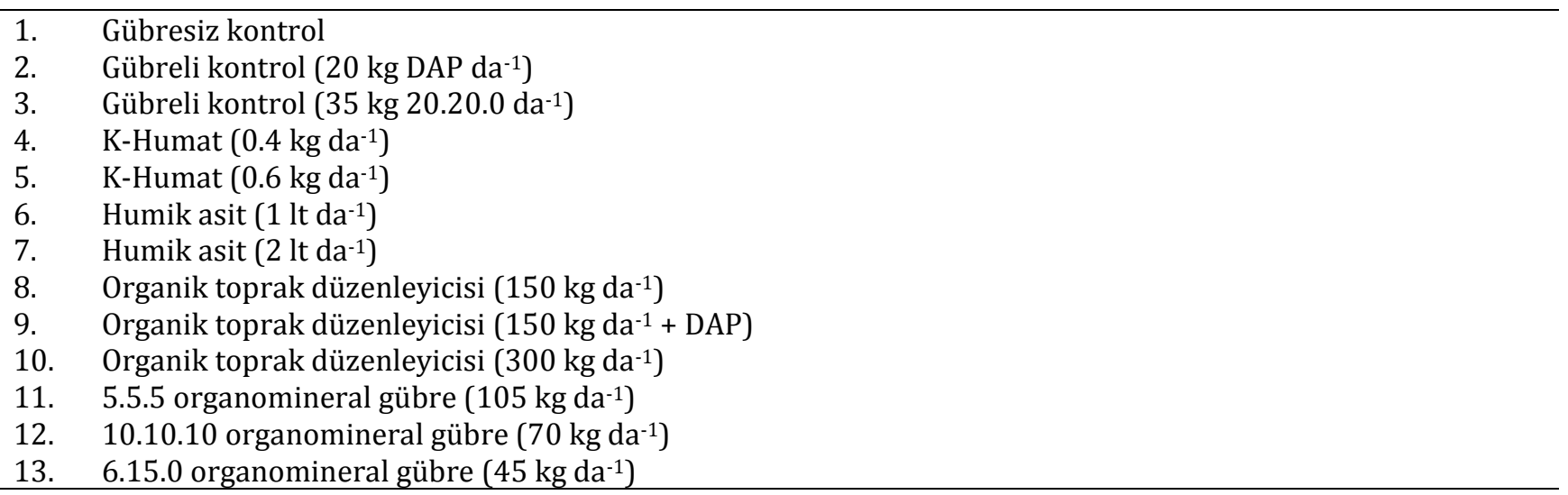

Denemenin kurulmasından 1 ay sonra ve denemenin 6. ayında toprak örneklemesi yapılarak toplam azot, yarayışlı fosfor, değișebilir potasyum, toprak reaksiyonu (pH), elektriksel iletkenlik (EC) ve kireç kapsamları belirlenmiş, deneme topraklarında organik maddeyi belirlemek amacıyla ise denemenin kurulmasından 1 ay sonra, 6. ayda ve hasat döneminde toprak örneklemeleri yapılmıștır.

Toprak örneklerinde, bünye hidrometre yöntemiyle (Bouyoucos, 1951), pH ve EC 1:2,5 toprak-su karıșımında (Jackson, 1958), kireç Scheibler kalsimetresi ile (Richards, 1954), organik madde Walkey Black yöntemiyle (Jackson, 1962), toplam azot Kjeldahl yöntemiyle (Bremner, 1965), değişebilir potasyum US Salinity Lab. Staff (1954)'a göre, alınabilir fosfor spektrofotometrik yöntem ile (Olsen ve ark., 1954) belirlenmiştir. Tarla denemesinden elde edilen sonuçlar Minitab 17.1.0 istatistik paket programı, varyans analizi ile değerlendirilmiştir. Önemlilik düzeyi $\mathrm{F}$ testine göre, ortalamaların farklılık gruplandırması ise "Duncan" testine göre yapılmıştır.

\section{Bulgular ve Tartışma}

\section{Uygulamaların toprak organik maddesi üzerine etkileri}

Kimyasal ve organomineral içerikli gübrelerin (organomineral) uygulandığı toprakların organik madde (OM) içeriği, 1.ay analiz sonuçlarına göre uygulamalar arasındaki fark istatistiksel olarak önemli bulunmamış, organomineral gübrelerin uygulanmasından 6 ay sonra topraklarda en düşük OM kontrol parselinde (\%1.077) belirlenirken, en yüksek organik toprak düzenleyicisi (150 kg da-1 + DAP) uygulamasında \%1.902 olarak saptanmıştır. Hasat toprakları analiz sonucuna göre de benzer şekilde en düşük OM değeri kontrol parselinde \% 0.909 olarak, en yüksek yine organik toprak düzenleyicisi (150 kg da-1 + DAP) uygulamasında \%1.609 belirlenmiştir (Çizelge 2). Tek başına organik materyallerin uygulandığı toprakların organik madde (OM) içeriği, 1.ay analiz sonuçlarına göre uygulamalar arasındaki fark istatistiksel olarak önemli bulunmamıș, organik materyallerin uygulanmasından 6 ay sonra topraklarda en düșük OM kontrol parselinde (\%1.077) belirlenirken, en yüksek organik toprak düzenleyicisi (300 kg da-1) \%1.980 olarak saptanmıştır. Hasat toprakları analiz sonucuna göre de benzer şekilde en düşük OM değeri kontrol parselinde \% 0.909 olarak, en yüksek yine organik toprak düzenleyicisi (300 kg da-1) uygulamasında $\% 1.675$ olarak belirlenmiştir (Çizelge 2). Toprak organik madde seviyesinin, farklı humik madde uygulamalarında önemli derecede artış gösterdiğini bildiren Turgay ve ark. (2011) elde edilen bulguları desteklemektedir. Toprağın organik madde seviyesinin 6. ayda başlangıca göre arttığı sonrasında ise tekrar azaldığ görülmüştür. İlk 6 ayda ilave edilen organik materyallerden toprağa geçen organik maddedeki azalma organik maddenin mineralizasyonundan kaynaklanmıştır. Araştırma sonucunda elde edilen bulgular Karaca ve ark. (2006), Tamer ve Karaca (2006)'nın çalışmaları ile uyumludur. 
Çizelge 2. Farklı uygulama faktörlerinin, zamana ve uygulama faktörlerine bağlı olarak ürün dönemi süresince toprakta belirlenen organik madde değerleri,

\begin{tabular}{|c|c|c|c|c|}
\hline & \multirow{2}{*}{ Uygulama Konuları } & \multicolumn{3}{|c|}{ Organik Madde $\%$} \\
\hline & & 1. AY & 6. AY & HASAT \\
\hline \multirow{7}{*}{ 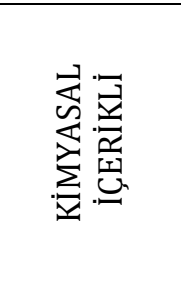 } & 1 - Gübresiz kontrol & 1.183 öd & $1.077 \mathrm{~b}$ & $0.909 \mathrm{~b}$ \\
\hline & 2- Gübreli kontrol (20 kg da-1 DAP) & 1.189 öd & $1.158 \mathrm{~b}$ & $1.092 \mathrm{ab}$ \\
\hline & 3- Gübreli kontrol (35 kg da-1 20.20.0) & 1.215 öd & $1.164 \mathrm{~b}$ & $1.049 \mathrm{~b}$ \\
\hline & 11- Organomineral gübre (7.7.0/ $\left.105 \mathrm{~kg} \mathrm{da}^{-1}\right)$ & 1.256 öd & $1.253 \mathrm{~b}$ & $1.319 \mathrm{a}$ \\
\hline & 12- Organomineral gübre (10.10.0 / $\left.70 \mathrm{~kg} \mathrm{da}^{-1}\right)$ & 1.200 öd & $1.198 \mathrm{~b}$ & $1.646 \mathrm{a}$ \\
\hline & 13- Organomineral gübre $\left(6.15 .0 / 45 \mathrm{~kg} \mathrm{da}^{-1}\right)$ & 1.102 öd & $1.098 \mathrm{~b}$ & $1.391 \mathrm{a}$ \\
\hline & 9- Organik toprak düzenleyicisi (150 $\left.\mathrm{kg} \mathrm{da}^{-1}+\mathrm{DAP}\right)$ & 1.413 öd & $1.902 \mathrm{a}$ & $1.609 \mathrm{a}$ \\
\hline \multicolumn{2}{|l|}{ LSD:P<0.05 } & \multicolumn{3}{|c|}{0.629} \\
\hline \multirow{7}{*}{ 竞 } & 1- Gübresiz kontrol & 1.183 öd & $1.077 \mathrm{~b}$ & $0.909 \mathrm{~b}$ \\
\hline & 4- K-Humat (0.4 kg da-1) & $1.201 \mathrm{öd}$ & $1.355 \mathrm{ab}$ & $1.722 \mathrm{a}$ \\
\hline & 5- K-Humat (0.6 kg da-1) & 1.210 öd & $1.317 \mathrm{~b}$ & $1.640 \mathrm{a}$ \\
\hline & 6- Humik asit (1 lt da-1) & 1.182 öd & $1.182 \mathrm{~b}$ & $1.550 \mathrm{a}$ \\
\hline & 7- Humik asit (2 lt da-1) & 1.220 öd & $1.247 \mathrm{~b}$ & $1.725 \mathrm{a}$ \\
\hline & 8- Organik toprak düzenleyicisi (150 kg da-1) & 1.445 öd & $1.642 \mathrm{a}$ & $1.609 \mathrm{a}$ \\
\hline & 10- Organik toprak düzenleyicisi (300 $\left.\mathrm{kg} \mathrm{da}^{-1}\right)$ & 1.550 öd & $1.980 \mathrm{a}$ & $1.675 \mathrm{a}$ \\
\hline LSD:P<0.05 & & & 0.629 & \\
\hline
\end{tabular}

\section{Uygulamaların Toprakların Bazı Makro Element İçeriklerine Etkileri \\ Toplam Azot}

Kimyasal ve organomineral içerikli gübrelerin uygulandığı toprakların toplam azot değeri, 1.ay analiz sonuçlarına göre en düşük kontrol parselinde (\%0.078) belirlenirken, en yüksek 12 numaralı uygulamada (70 kg da-1 organik materyalin 10.10 .0 dozlarında kimyasal gübreyle karışımı) \%0.121 olarak saptanmıştır (Çizelge 3). Hasat toprakları analiz sonucuna göre ise en düşük azot değeri kontrol parselinde \%0,055 olarak, en yüksek ise organik toprak düzenleyicinin DAP ile birlikte uygulandığı (150 kg da-1 + DAP) toprakta \% 0,075 belirlenmiştir. Hasat döneminde tüm uygulama konularında belirlenen azot düzeyleri 1.ayda belirlenen azot değerlerinden daha düşük belirlenmiștir. Her iki dönemde de bütün uygulama konularında belirlenen azot değerleri kontrol parselinden daha yüksek belirlenmiștir. Denemenin 1. ayında toprakların azot değerlerinin kontrol topraklarında belirlenen değerlerin üzerinde belirlenmesi istatistiksel olarak $\mathrm{p}<0.05$ düzeyinde önemli bulunmuş ancak hasat dönemi topraklarının azot içeriklerinde belirlenen değişimler istatistiksel olarak önemli bulunmamıştır (Çizelge 3). Tek başına organik materyallerin uygulandığı toprakların toplam azot değeri, 1.ay analiz sonuçlarına göre en düşük kontrol parselinde \% 0.078 olarak belirlenirken, en yüksek ise $\mathrm{K}$-Humat $0.6 \mathrm{~kg}^{-1 a^{-1}}$ uygulamasında \%0.118 olarak saptanmıștır. Hasat toprakları analiz sonucuna göre ise en düşük azot değeri yine kontrol uygulamasında \%0.055 olarak, en yüksek yine K-Humat ( $\left.0.6 \mathrm{~kg} \mathrm{da}^{-1}\right)$ uygulamasında $\% 0.078$ olarak belirlenmiştir. Hasat döneminde tüm uygulama konularında belirlenen azot düzeyleri 1. ayda belirlenen azot değerlerinden daha düşük belirlenmiștir. 1. ay topraklarında belirlenen bu farklılıklar istatistiksel olarak $\mathrm{P}<0.05$ düzeyinde önemli bulunmuş hasat dönemi topraklarının azot içeriklerinde belirlenen değişimler istatistiksel olarak önemli bulunmamıştır (Çizelge 3).

Deneme topraklarının toplam azot konsantrasyonlarının yetiştirme süresine bağlı olarak azalması, buğday bitkisinin gelişme dönemi boyunca toprak azotundan yararlanmasının yanı sıra, mevcut şartlar altında denitrifikasyon ve/veya amonifikasyona bağlı gaz halde azot kayıplarının meydana gelmiş olabileceğini göstermektedir. Uygulamalara bağlı değişim incelendiğinde, NP gübresi ile birlikte organik toprak düzenleyicinin birlikte verildiği uygulamalarda toplam azotun daha fazla belirlenmiş olması, organik maddenin toprakta azot yarayışlılığını artırdığını göstermektedir. Leonardit ve azot gübresinin birlikte uygulanması durumunda leonarditin azotun yarayışlılığını arttırabileceğini belirten Erol (1992), Tamer ve Karaca (2011) elde edilen bulguları desteklemektedir.

\section{Yarayışlı Fosfor}

Kimyasal ve organomineral içerikli gübrelerin uygulandığı toprakların yarayışlı fosfor (P) değeri, 1.ay analiz sonuçlarına göre en düşük kontrol parselinde $\left(6.518 \mathrm{mg} \mathrm{kg}^{-1}\right.$ ) belirlenirken, en yüksek $20 \mathrm{~kg} \mathrm{da}^{-1} \mathrm{DAP}$ uygulamasında $9.386 \mathrm{mg} \mathrm{kg}^{-1}$ olarak saptanmıştır. Hasat toprakları analiz sonucuna göre ise en düşük yarayışlı P değeri kontrol parselinde $5.431 \mathrm{mg} \mathrm{kg}^{-1}$ olarak, en yüksek ise 6.15 .0 organomineral gübresinin 45 
$\mathrm{kg} \mathrm{da}^{-1}$ uygulamasında $7.55 \mathrm{mg} \mathrm{kg}^{-1}$ belirlenmiştir (Çizelge 3). Hasat döneminde tüm uygulama konularında belirlenen yarayıșlı $\mathrm{P}$ düzeyleri 1.ayda belirlenen $\mathrm{P}$ değerlerinden daha düşük belirlenmiștir. Her iki dönemde de bütün uygulama konularında belirlenen $\mathrm{P}$ değerleri kontrol parselinden daha yüksek belirlenmiş ve toprakların $P$ değerlerinin kontrol topraklarında belirlenen değerlerin üzerinde belirlenmesi istatistiksel olarak p<0.05 düzeyinde önemli bulunmuştur. Tek başına organik materyallerin uygulandığg toprakların yarayışlı P değeri, 1. ay analiz sonuçlarına göre en düşük kontrol parselinde, en yüksek ise 2 lt $\mathrm{da}^{-1}$ humik asit uygulamasında $11.199 \mathrm{mg} \mathrm{kg}^{-1}$ olarak saptanmıştır. Hasat toprakları analiz sonuçları da benzer şekilde en düşük kontrol topraklarında (5.431 $\mathrm{mg} \mathrm{kg}^{-1}$ ) ve en yüksek $2 \mathrm{lt} \mathrm{da}^{-1}$ Humik asit uygulamasında (7.566 mg kg-1) belirlenmiştir. Hasat döneminde tüm uygulama konularında belirlenen yarayışlı P düzeyleri 1. ayda belirlenen $P$ değerlerinden daha düşük belirlenmiştir. Her iki dönemde de bütün uygulama konularında belirlenen $\mathrm{P}$ değerleri kontrol parselinden daha yüksek belirlenmiş ve toprakların $\mathrm{P}$ değerlerinin kontrol topraklarında belirlenen değerlerin üzerinde bulunması istatistiksel olarak $\mathrm{p}<0.05$ düzeyinde önemli bulunmuştur. Tüm uygulamalarda belirlenen toprakların alınabilir P kapsamları yeterli durumdadır ve toprağa organik materyal ilavesi yarayışlı fosfor miktarını artırmıştır. Son yıllarda yapılan çalışmalarda, toprağa karıştırılan organik materyallerin topraktaki fosforu bitki için daha yararlı hale getirdiği görülmüştür.

Alkali özellikli topraklara fosforlu gübre ve humik asit uygulamasının bitkinin fosfor alımını ve bitki kuru ağırlığını artırdığı Wang ve ark. (1995) tarafından da bildirilmiştir. Toprak organik maddesinin, ilave edilen fosforun Al-P, Fe-P ve Ca-P ile olan reaksiyonlarını geciktirerek yarayışlı fosfor miktarını arttırdığını belirten Tomer ve ark. (1984) ve yarayışlı fosforun, farklı humik madde uygulamalarında önemli derecede artış gösterdiğini bildiren Turgay ve ark. (2011) elde edilen bulguları desteklemektedir. Erdal ve ark. (1999) humik asitin N, P, K gübreleri ile birlikte verilmesi durumunda elde edilen ürün artışının humik asitin tek başına verilmesinden elde edilen artıştan daha fazla olduğunu ve ayrıca humik asit uygulanması ile topraktaki P yarayışlılığının arttığını, Karabatak (2006) ise yüksek dozlarda uygulanan organik gübrenin bitkiye yarayışlı $\mathrm{P}$ fraksiyonlarında artışa neden olduğunu, mineral formda verilen fosforun farklı fraksiyonlardaki dağlımının organik gübrenin çeşidi, fosfor içeriği, dozu ve toprak özellikleri tarafından etkilendiğini belirtmişlerdir.

\section{Değișebilir Potasyum}

Kimyasal ve organomineral içerikli gübrelerin uygulandığı toprakların değişebilir potasyum (K) değeri, 1 . ay analiz sonuçlarına göre en düşük kontrol parselinde (69.48 $\mathrm{mg} \mathrm{kg}^{-1}$ ) belirlenirken, en yüksek $20 \mathrm{~kg} \mathrm{da}^{-1} \mathrm{DAP}$ uygulamasında $85.37 \mathrm{mg} \mathrm{kg}^{-1}$ olarak saptanmıștır (Çizelge 3). Hasat toprakları analiz sonucuna göre ise en düşük değişebilir $\mathrm{K}$ değeri kontrol parselinde $63.40 \mathrm{mg} \mathrm{kg}^{-1}$ olarak, en yüksek ise 6.15 .0 organomineral gübresinin $45 \mathrm{~kg} \mathrm{da}^{-1}$ uygulamasında $91.84 \mathrm{mg} \mathrm{kg}^{-1}$ belirlenmiştir. Hasat döneminde tüm uygulama konularında belirlenen değişebilir K düzeyleri 1.ayda belirlenen $\mathrm{K}$ değerlerinden daha düşük belirlenmiştir. Organik toprak düzenleyicisi (150 kg da-1 + DAP) uygulaması hariç, bu uygulamada hasat toprağının değişebilir K değeri başlangıca göre artış göstermiştir. Her iki dönemde de bütün uygulama konularında belirlenen değişebilir K değerleri kontrol parselinden daha yüksek belirlenmiş ve toprakların değişebilir $\mathrm{K}$ değerlerinin kontrol topraklarında belirlenen değerlerin üzerinde belirlenmesi istatistiksel olarak p $<0.05$ düzeyinde önemli bulunmuştur. Tek başına organik materyallerin uygulandığı toprakların değisşebilir $\mathrm{K}$ değeri, 1.ay analiz sonuçlarına göre en düşük kontrol parselinde (69.48 $\left.\mathrm{mg} \mathrm{kg}^{-1}\right)$ ve en yüksek ise $300 \mathrm{~kg} \mathrm{da}^{-}$ ${ }^{1}$ organik toprak düzenleyicisi uygulamasında $80.05 \mathrm{mg} \mathrm{kg}^{-1}$ olarak saptanmıştır. Hasat toprakları analiz sonuçları da benzer şekilde en düşük kontrol topraklarında (63.40 mg kg-1) ve en yüksek $300 \mathrm{~kg} \mathrm{da}^{-1}$ organik $^{-1}$ toprak düzenleyicisi uygulamasında $(74.28 \mathrm{mg} \mathrm{kg}-1)$ belirlenmiştir. Hasat döneminde tüm uygulama konularında belirlenen değişebilir K düzeyleri 1. ayda belirlenen değişebilir K değerlerinden daha düşük belirlenmiştir. Her iki dönemde de bütün uygulama konularında belirlenen değişebilir $\mathrm{K}$ değerleri kontrol parselinden daha yüksek belirlenmiş ve toprakların değișebilir $\mathrm{K}$ değerlerinin kontrol topraklarında belirlenen değerlerin üzerinde bulunması istatistiksel olarak $\mathrm{p}<0.05$ düzeyinde önemli bulunmuştur.

Topraklarda değişebilir potasyum miktarının 40-150 mg kg-1 arasında değisştiği ve değişebilir potasyumun 150 mg kg-1 olduğu zaman bitkilerde beslenme yönünden bir sorun olmayacağı Barber (1985) tarafından bildirilmiştir. Buna göre deneme parsellerinin değișebilir $\mathrm{K}$ bakımından orta düzeyde olduğu söylenebilir. Organomineral gübre uygulamalarında belirlenen değișebilir potasyumun zamana bağlı artış gösterdiği belirlenmiş̦tir. Deneme topraklarında belirlenen değișebilir potasyumun yetiștirme süresine bağlı olarak artışının, organik toprak düzenleyicilerin içerdiği organik maddeden etkilendiği, organik maddenin toprakta değişebilir K'un yarayışlılığını artırdığı düşünülmüştür. Uygulamalar arasındaki değişimler incelendiğinde; kontrol ya da yalnız NP verilmiş olan uygulamalara kıyasla leonardit içeren uygulamalarda değișebilir K'un 
daha fazla bulunmuş olması bu sonucu desteklemektedir. Fikse edilmiş potasyumun serbest hale geçmesine humik ve fulvik asitin etkisinin olumlu olduğunu belirten Tan (1978) ile elde edilen bulgular uyumludur.

Çizelge 3. Farklı uygulama faktörlerinin, zamana ve uygulama faktörlerine bağlı olarak ürün dönemi süresince toprakların N, P, K değerleri

\begin{tabular}{|c|c|c|c|c|c|c|}
\hline & & \multicolumn{2}{|c|}{$\begin{array}{c}\text { Toplam Azot } \\
\%\end{array}$} & \multicolumn{2}{|c|}{$\begin{array}{c}\text { Yarayıșlı Fosfor } \\
\text { mg kg-1 }^{-1}\end{array}$} & $\begin{array}{l}\text { Değişebilir } \\
\text { Potasyum } \\
\text { mg kg-1 }^{-1}\end{array}$ \\
\hline & & 1.AY & HASAT & 1.AY & HASAT & 1.AY HASAT \\
\hline \multirow{7}{*}{ 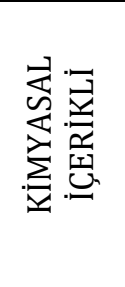 } & 1 - Gübresiz kontrol & $0,07 \mathrm{~b}$ & 0,05 öd & $6,51 \mathrm{c}$ & $5,43 \mathrm{~b}$ & $69,48 \mathrm{~cd} \quad 63,40 \mathrm{c}$ \\
\hline & 2- Gübreli kontrol (20 kg da-1 DAP) & $0,10 \mathrm{a}$ & 0,06 öd & $9,38 \mathrm{a}$ & $7,04 \mathrm{a}$ & 85,37 a 81,31 b \\
\hline & 3- Gübreli kontrol (35 kg da-1 20.20.0) & $0,11 \mathrm{a}$ & 0,06 öd & $8,92 \mathrm{ab}$ & 7,18 a & 82,26 ab $84,58 a b$ \\
\hline & 11- Organomineral gübre (7.7.0/ $\left.105 \mathrm{~kg} \mathrm{da}^{-1}\right)$ & $0.11 \mathrm{a}$ & 0.06 öd & $9.13 \mathrm{ab}$ & $5.90 \mathrm{~b}$ & $69.97 \mathrm{~cd} 81.91 \mathrm{~b}$ \\
\hline & 12- Organomineral gübre (10.10.0 / $\left.70 \mathrm{~kg} \mathrm{da}^{-1}\right)$ & $0.12 \mathrm{a}$ & 0.06 öd & $9.13 \mathrm{ab}$ & $5.35 \mathrm{~b}$ & $73.00 \mathrm{~cd} 78.19 \mathrm{~b}$ \\
\hline & 13- organomineral gübre $\left(6.15 .0 / 45 \mathrm{~kg} \mathrm{da}^{-1}\right)$ & $0.09 \mathrm{ab}$ & 0.07 öd & $8.06 \mathrm{~b}$ & $7.55 \mathrm{a}$ & $74.08 \mathrm{bc} 91.84 \mathrm{a}$ \\
\hline & 9- Organik toprak düzenleyicisi (150 $\left.\mathrm{kg} \mathrm{da}^{-1}+\mathrm{DAP}\right)$ & $0.11 \mathrm{a}$ & 0.07 öd & $9.12 \mathrm{ab}$ & & 83.95 a $75.37 b c$ \\
\hline \multicolumn{2}{|r|}{ LSD $\mathrm{P}<0.05$} & \multicolumn{2}{|c|}{0.0382} & \multicolumn{2}{|c|}{1.299} & 8.70 \\
\hline \multirow{7}{*}{ 岂: } & 1- Gübresiz kontrol & $0.07 \mathrm{~b}$ & $0.05 \mathrm{öd}$ & $6.518 \mathrm{c}$ & $5.43 \mathrm{bc}$ & $69.48 \mathrm{bc} \quad 63.40 \mathrm{~b}$ \\
\hline & 4- K-Humat (0.4 $\left.\mathrm{kg} \mathrm{da}^{-1}\right)$ & $0.09 \mathrm{bc}$ & 0.06 öd & $8.496 \mathrm{~b}$ & $5.89 \mathrm{c}$ & $73.57 \mathrm{~b}$ \\
\hline & 5- K-Humat (0.6 kg da-1) & $0.11 \mathrm{a}$ & 0.07 öd & $10.727 \mathrm{a}$ & $7.28 \mathrm{a}$ & $77.69 \mathrm{a}$ \\
\hline & 6- Humik asit (1 lt da-1) & $0.10 \mathrm{ab}$ & 0.06 öd & $9.057 \mathrm{~b}$ & $6.11 \mathrm{ab}$ & $74.58 \mathrm{ab}$ \\
\hline & 7- Humik asit (2 lt da-1) & $0.07 \mathrm{c}$ & 0.06 öd & $11.199 \mathrm{a}$ & $7.56 \mathrm{a}$ & $72.76 \mathrm{~b}$ \\
\hline & 8- Organik toprak düzenleyicisi (150 $\mathrm{kg} \mathrm{da}^{-1}$ ) & $0.09 \mathrm{bc}$ & 0.06 öd & $6.163 \mathrm{c}$ & $5.47 \mathrm{~b}$ & $70.06 \mathrm{~b}$ \\
\hline & 10- Organik toprak düzenley & $0.09 \mathrm{~b}$ & 0.07 öd & $6.666 \mathrm{c}$ & $5.47 \mathrm{~b}$ & $80.05 \mathrm{a} \quad 74.28 \mathrm{a}$ \\
\hline \multicolumn{2}{|c|}{ LSD:P<0.05 } & \multicolumn{2}{|c|}{0.0382} & \multicolumn{2}{|c|}{1.299} & 8.70 \\
\hline
\end{tabular}

\section{Uygulamaların topraklarının toprak reaksiyonu (pH) ve elektriksel iletkenlik (EC) ve kireç kapsamları üzerine etkileri}

Denemenin kurulmasından 1 ay sonra ve 6. ayında toprak örneklemesi yapılarak belirlenmiş ve elde edilen sonuçlar Çizelge 4'de verilmiştir.

\section{Toprak reaksiyonu (pH)}

Kimyasal ve organomineral içerikli gübrelerin uygulandığı toprakların pH değeri, 1 . ay analiz sonuçlarına göre en düşük kontrol parselinde 7.81 belirlenirken, en yüksek $35 \mathrm{~kg} \mathrm{da}^{-1} 20.20 .0$ (gübreli kontrol) uygulamasında 8.09 olarak saptanmıștır (Çizelge 4). Hasat toprakları analiz sonucuna göre ise; en düşük pH değeri yine kontrol parselinde 7.86 olarak, en yüksek ise 7.7.0 organomineral gübresinin $105 \mathrm{~kg} \mathrm{da}^{-1}$ uygulamasında belirlenmiştir. Tüm uygulamaların kontrole göre toprağın $\mathrm{pH}$ değerini bir miktar artırdığı belirlenmiştir. Tek başına organik materyallerin uygulandığı toprakların $\mathrm{pH}$ değeri, 1. ay analiz sonuçlarına göre en düşük kontrol parselinde 7.81 olarak aynı belirlenirken, en yüksek ise $0.6 \mathrm{~kg} \mathrm{da}^{-1} \mathrm{~K}$-Humat uygulamasında 8.05 olarak saptanmıștır. Hasat topraklarında toprakların pH değerlerinde uygulamalara bağlı meydana gelen değişimler istatistiksel olarak önemli bulunmamıştır. Deneme parsellerinin tamamında toprak reaksiyonu hafif-orta alkali durumundadır.

\section{Toprakta elektriksel iletkenlik (EC)}

Kimyasal ve organomineral içerikli gübrelerin uygulandığı toprakların gerek 1. ay gerekse hasat döneminde uygulamalara bağlı EC değerinde meydana gelen değişimler istatistiksel olarak önemli bulunmamıştır. Tek başına organik materyallerin uygulandığı toprakların EC değeri, 1. ay ve hasat dönemi analiz sonuçlarına göre en düşük kontrol parselinde (0.235 ve $0.224 \mathrm{dS} \mathrm{m}^{-1}$ sırasıyla) belirlenirken, en yüksek ise $300 \mathrm{~kg}$ da${ }^{1}$ organik toprak düzenleyicisi uygulamasında sırasıyla 0.350 ve $0.426 \mathrm{dS} \mathrm{m}^{-1}$ olarak saptanmıştır (Çizelge 4). Uygulamalar arasında belirlenen farklar istatistiksel olarak $\mathrm{p}<0.05$ düzeyinde önemli bulunmuştur.

Kirven (1986) sature ortam ekstraktını esas alan çalışmalarda organik materyallerin EC kapsamlarının 2-4 $\mathrm{dS} \mathrm{m}^{-1}$ nin orta, 4-6 $\mathrm{dS} \mathrm{m}^{-1}$ 'nin yüksek 4-8 $\mathrm{dS} \mathrm{m}^{-1}$ nin ancak iyi gelişmiş bitkiler için uygun olduğunu belirtmiştir. Bildirilen sınır değerleri ve bitkilerin tuza duyarlılıkları farklı olmakla beraber, $4 \mathrm{dS} \mathrm{m}^{-1} \mathrm{nin}$ üzerindeki elektriksel iletkenlik değerleri risk taşımaktadır. Bu değerlere göre deneme topraklarının EC değerleri $4 \mathrm{dS} \mathrm{m}^{-1}$ 'den düşük olup tarımsal açıdan bir risk bulunmasa da, tek başına organik materyal uygulamalarına bağlı toprakların EC değerlerinde artış meydana gelmiş olmasından ötürü bu organik materyallerin kullanımlarında dikkatli ve kontrollü olunmasında yarar bulunmaktadır. 
Çizelge 4. Farklı uygulama faktörlerinin, zamana ve uygulama faktörlerine bağlı olarak ürün dönemi süresince toprakta belirlenen Kireç, pH, EC değerleri

\begin{tabular}{|c|c|c|c|c|c|c|c|}
\hline & & \multicolumn{2}{|c|}{$\begin{array}{c}\text { Kireç } \\
\% \\
\end{array}$} & \multicolumn{2}{|c|}{$\mathrm{pH}$} & \multicolumn{2}{|c|}{$\begin{array}{c}\text { EC } \\
\mathrm{dS} \mathrm{m}^{-1}\end{array}$} \\
\hline & & 1.AY & HASAT & 1.AY & HASAT & 1.AY & HASAT \\
\hline \multirow{7}{*}{ 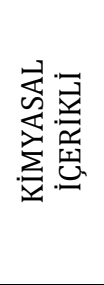 } & 1 - Gübresiz kontrol & 22.63 öd & 22.13 öd & $7.81 \mathrm{~b}$ & $7.86 \mathrm{~b}$ & 0.23 öd & 0.22 öd \\
\hline & 2- Gübreli kontrol (20 kg da-1 DAP) & 22.91 öd & 22.27 öd & $8.00 \mathrm{a}$ & $7.97 \mathrm{~b}$ & 0.26 öd & 0.25 öd \\
\hline & 3- Gübreli kontrol (35 kg da-1 20.20.0) & 21.48 öd & 22.71 öd & $8.09 \mathrm{a}$ & $7.90 \mathrm{~b}$ & 0.20 öd & 0.27 öd \\
\hline & 11- Organomineral gübre (7.7.0/ $\left.105 \mathrm{~kg} \mathrm{da}^{-1}\right)$ & 22.92 öd & 22.54 öd & $7.86 \mathrm{~b}$ & $8.03 \mathrm{a}$ & 0.19 öd & 0.26 öd \\
\hline & 12-Organomineral gübre $\left(10.10 .0 / 70 \mathrm{~kg} \mathrm{da}^{-1}\right)$ & 22.81 öd & 21.90 öd & $8.06 \mathrm{a}$ & $8.02 \mathrm{a}$ & 0.22 öd & 0.27 öd \\
\hline & 13- organomineral gübre $\left(6.15 .0 / 45 \mathrm{~kg} \mathrm{da}^{-1}\right)$ & 22.41 öd & 22.57 öd & $8.02 \mathrm{a}$ & $8.01 \mathrm{ab}$ & 0.27 öd & 0.25 öd \\
\hline & 9- Organik toprak düz & 22.27 öd & 22.63 öd & $7.95 \mathrm{~b}$ & $8.00 \mathrm{ab}$ & 0.29 öd & 0.30 öd \\
\hline \multicolumn{2}{|c|}{ LSD:P<0.05 } & \multicolumn{2}{|c|}{2.423} & \multicolumn{2}{|c|}{0.156} & \multicolumn{2}{|c|}{0.126} \\
\hline \multirow{7}{*}{ 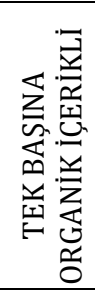 } & 1- Gübresiz kontrol & 22.63 öd & 22.13 öd & $7.81 \mathrm{~b}$ & 7.86 öd & $0.23 \mathrm{~b}$ & $0.22 \mathrm{~b}$ \\
\hline & 4- K-Humat (0.4 $\left.\mathrm{kg} \mathrm{da}^{-1}\right)$ & 23.99 öd & 22.23 öd & $8.03 \mathrm{a}$ & 7.96 öd & $0.32 \mathrm{a}$ & $0.39 \mathrm{a}$ \\
\hline & 5- K-Humat $\left(0.6 \mathrm{~kg} \mathrm{da}^{-1}\right)$ & 22.88 öd & 22.83 öd & $8.05 \mathrm{a}$ & 7.89 öd & $0.39 \mathrm{a}$ & $0.33 \mathrm{a}$ \\
\hline & 6- Humik asit (1 lt da-1) & 23.52 öd & 22.12 öd & $8.03 \mathrm{a}$ & 7.88 öd & $0.29 \mathrm{a}$ & $0.39 \mathrm{a}$ \\
\hline & 7- Humik asit (2 lt da-1) & 23.06 öd & 22.36 öd & $8.04 \mathrm{a}$ & 7.94 öd & $0.30 \mathrm{a}$ & $0.31 \mathrm{ab}$ \\
\hline & 8- Organik toprak düzenleyicisi (150 kg da-1) & 10.76 öd & 21.74 öd & $8.07 \mathrm{a}$ & 7.92 öd & $0.30 \mathrm{a}$ & $0.31 \mathrm{ab}$ \\
\hline & 10- Organik toprak düzenleyicisi $\left(300 \mathrm{~kg} \mathrm{da}^{-1}\right)$ & 21.06 öd & 22.72 öd & $7.98 \mathrm{a}$ & 7.92 öd & $0.35 \mathrm{a}$ & $0.42 \mathrm{a}$ \\
\hline \multicolumn{2}{|c|}{ LSD $: \mathrm{P}<0.05$} & \multicolumn{2}{|c|}{2.423} & \multicolumn{2}{|c|}{0.156} & \multicolumn{2}{|c|}{0.126} \\
\hline
\end{tabular}

\section{Kireç}

Gerek kimyasal ve organomineral içerikli gübrelerin uygulandığı toprakların gerekse tek başına organik materyallerin uygulandığı toprakların kireç içeriklerinde uygulamalara bağlı meydana gelen değişimler istatistiksel olarak önemli bulunmamıştır (Çizelge 4). Deneme parsellerinin tamamı kireç bakımından zengindir.

\section{Uygulamaların Buğday Tanesine Ait Analiz Sonuçları ve Verim Bileşenleri Üzerine Etkileri}

Denemenin hasat edilmesiyle birlikte parsellerden elde edilen verim ve verim bileșenlerine ait veriler Çizelge 5'de verilmiştir.

\section{Buğday Tanesi Azot ve Protein İçeriği}

Kimyasal ve organomineral içerikli gübrelerin uygulandığı parsellerden hasat edilen buğday bitkisi tanesinin $\mathrm{N}$ ve protein kapsamları en düşük kontrol parsellerinde sırasıyla $\% 1.913$ ve $\% 12$, en yüksek tane $\mathrm{N}$ ve protein değerleri ise organomineral gübre $\left(6.15 .0 / 45 \mathrm{~kg} \mathrm{da}^{-1}\right)$ uygulamasında sirasıyla \%2.241 ve \%13.82 olarak belirlenmiştir. Tek başına organik materyallerin uygulandığı parsellerden hasat edilen buğday bitkisi tanesinin N ve protein kapsamları en düşük kontrol parsellerinde sirasiyla \%1.913 ve \% 12, en yüksek tane $\mathrm{N}$ ve protein değerleri ise K-Humat $\left(0.6 \mathrm{~kg} \mathrm{da}^{-1}\right)$ uygulamasında sirasılyla \%2.136 ve \%13.50 olarak belirlenmiştir (Çizelge 5).

Buğday protein oranı, çeşide ve daha çok çevre koşullarına bağlı olarak \%6-22 arasında değişmektedir (Ünal, 2002). Köksal ve ark. (2000) en yüksek protein oranını \% 14.80 ile "Bezostaja" çeşidinden elde ettiklerini belirtmişler, Efimov ve Vertii (1971) de "Bezostaja" çeşidine NPK gübre uygulamasıyla protein değerlerinin \% 13.7'den \%15.2'ye yükseldiğini bildirmişlerdir. Protein oranı; genotip, yağış miktarı, yağışıı aylara göre dağılımı, sıcaklık, toprak özellikleri gibi çevresel faktörlere göre değişebilmektedir (Atlı, 1999). Yetiştirme teknikleri ile süne ve kımıl zararı da protein oranı ve kalitesi üzerinde önemli faktörlerdir. Genel olarak bakıldığında tüm parsellerde belirlenen protein oranları, yapılmış çalışmalarda belirtilen değerler arasındadır. Yanısıra, kimyasal ve organomineral içerikli gübrelerin birlikte uygulandığı (organomineral gübre) parsellerde buğday bitkisi tane protein oranı tek başına kullanımlarından bir miktar daha yüksek bulunmuştur.

\section{Verim}

Kimyasal ve organomineral içerikli gübrelerin uygulandığı parsellerden elde edilen dekara buğday verimi en düşük kontrol parselinde $304 \mathrm{~kg}$, en yüksek dekara verim ise Organik toprak düzenleyicisi $\left(150 \mathrm{~kg} \mathrm{da}^{-1}+\right.$ DAP) uygulamasında $467 \mathrm{~kg}$ olarak belirlenmiştir. Tek başına organik materyallerin uygulandığı parsellerden elde edilen dekara buğday verimi yine en düşük kontrol parselinde, en yüksek ise K-Humat $(0.6$ $\mathrm{kg} \mathrm{da}^{-1}$ ) uygulanmış parsellerde $438.85 \mathrm{~kg}$ olarak belirlenmiştir.

Denemenin yürütüldüğü Haymana Araştırma ve Uygulama Çiftliğinde $20 \mathrm{~kg} \mathrm{da}^{-1}$ DAP gübresi uygulanarak yetiştirilen" Bezostaja" buğday parsellerinde 2016 yılında ortalama 390 kg verim alındığı yetkili kişiler 
tarafından belirtilmiştir. Bu sonuç, araştırmada tek başına DAP uygulanmış parsellerle uyum içerisindedir. Yörenin geleneksel uygulaması olan tek başına $20 \mathrm{~kg} \mathrm{da}^{-1}$ DAP uygulamasına kıyasla toprağa ilave edilen organik materyallerin tek başlarına ve kimyasal gübrelerle birlikte uygulanması buğday verimini önemli düzeyde artırmıştır. Gerek tek başına organik materyallerin toprağa uygulanması gerekse organik materyallerin kimyasal gübrelerin yanında toprağa uygulanması verimi önemli derecede artırmıştır. Organik materyallerin tek başına ve organomineral gübrenin toprağa uygulanması tane verimi üzerine olumlu etki etmiştir. Özellikle farklı çeşitlerin reaksiyonlarını daha iyi ortaya koyabilmek amacıyla, iklim koşullarının etkileri ve uygulanan organik toprak düzenleyicileri ile organomineral gübrelerin içeriği ile bitkilerin gerek duyduğu besin elementlerinin uyuşup uyuşmadı̆̆ gibi konularda daha fazla bilgi toplamak ve pratikte buğday üretimine güvenilir bir şekilde aktarabilmek için mevcut çalışmanın birkaç yıl daha yürütülmesi önem taşımaktadır.

\section{Bitki Boyu}

Kimyasal ve organomineral içerikli gübrelerin uygulandığı parsellerden elde edilen bitki boyu değerleri en düşük kontrol parselinde $98.5 \mathrm{~cm}$, en yüksek bitki boyu ise 7.7.0 Organomineral gübrenin $105 \mathrm{~kg} \mathrm{da}^{-1}$ uygulamasında $113.5 \mathrm{~cm}$ olarak belirlenmiştir. Tek başına organik materyallerin uygulandığı parsellerden elde edilen en düşük bitki boyu kontrol parselinde, en yüksek ise $0.6 \mathrm{~kg} \mathrm{da}^{-1} \mathrm{~K}$-Humat uygulanmış parsellerde $107 \mathrm{~cm}$ olarak belirlenmiştir. Organik materyal uygulaması bitki boyunu artırmıştır. Bitki boyu; çeşidin genetik yapısı, ekim sıklı̆̆ı, ekim zamanı, yağış durumu, gübreleme ve toprak şartlarına göre değişmektedir (Yürür ve ark., 1981; Gençtan ve Sağlam, 1987; Kün, 1988). Bitki boyu, hasat indeksi ve yatmaya etkisi yönünden önemli morfolojik özelliklerden biridir (Kırtok ve ark., 1987; Kün, 1996). Dönmez (2002)'in 25 ekmeklik buğday çeşidinde Haymana'da belirlediği bitki boyu ortalamalarından $(55.3-83.2 \mathrm{~cm})$ ise nispeten yüksektir. Kaya ve ark. (2005) Ankara Üniversitesi Ziraat Fakültesi Araştırma Uygulama Çiftliğinde, tohuma çinko ve yapraktan humik asit uygulamalarının ekmeklik buğdayda yürüttüğü tarla denemesinde, ilk yıl bitki boyunu $106.7-112.3 \mathrm{~cm}$, ikinci yılda, ise 107.6-112.6 cm arasında bulmuştur.

Çizelge 5. Farklı uygulama faktörlerinin, zamana ve uygulama faktörlerine bağlı olarak ürün dönemi süresince tanede belirlenen $\mathrm{N}$, protein, verim ve bitki boyu değerleri

\begin{tabular}{|c|c|c|c|c|c|}
\hline & & $\begin{array}{c}\text { Azot } \\
\%\end{array}$ & $\begin{array}{c}\text { Protein } \\
\%\end{array}$ & $\begin{array}{l}\text { Verim } \\
\mathrm{kg} \mathrm{da}^{-1}\end{array}$ & $\begin{array}{c}\text { Bitki boyu, } \\
\mathrm{cm}\end{array}$ \\
\hline \multirow{7}{*}{ 焉丞 } & 1 - Gübresiz kontrol & $12.00 \mathrm{~d}$ & $1.913 \mathrm{c}$ & $304.58 \mathrm{~d}$ & $98.50 \mathrm{c}$ \\
\hline & 2- Gübreli kontrol (20 kg da-1 DAP) & $12.30 \mathrm{~cd}$ & $1.979 \mathrm{bc}$ & $387.81 \mathrm{~cd}$ & $100.50 \mathrm{c}$ \\
\hline & 3- Gübreli kontrol (35 kg da-1 20.20.0) & $13.80 \mathrm{a}$ & $2.169 \mathrm{a}$ & $391.46 \mathrm{bc}$ & $101.50 \mathrm{c}$ \\
\hline & 11- Organomineral gübre (7.7.0/ $\left.105 \mathrm{~kg} \mathrm{da}^{-1}\right)$ & $13.40 \mathrm{ab}$ & $2.110 \mathrm{ab}$ & $426.88 \mathrm{ab}$ & $113.50 \mathrm{a}$ \\
\hline & 12-Organomineral gübre $\left(10.10 .0 / 70 \mathrm{~kg} \mathrm{da}^{-1}\right)$ & $13.10 \mathrm{bc}$ & $2.123 \mathrm{ab}$ & $415.83 \mathrm{ab}$ & $110.75 \mathrm{ab}$ \\
\hline & 13- organomineral gübre $\left(6.15 .0 / 45 \mathrm{~kg} \mathrm{da}^{-1}\right)$ & $13.82 \mathrm{a}$ & $2.241 \mathrm{a}$ & $456.56 \mathrm{ab}$ & $105.50 \mathrm{ab}$ \\
\hline & 9- Organik toprak düzenleyicisi (150 $\left.\mathrm{kg} \mathrm{da}^{-1}+\mathrm{DAP}\right)$ & $13.00 \mathrm{bc}$ & $1.977 \mathrm{bc}$ & $467.08 \mathrm{a}$ & $103.50 \mathrm{bc}$ \\
\hline LSD: & $\mathrm{P}<0.05$ & 0.408 & 0.21715 & 66.672 & 8.0258 \\
\hline \multirow{7}{*}{ 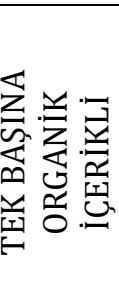 } & 1- Gübresiz kontrol & $12.00 \mathrm{~d}$ & $1.913 \mathrm{~b}$ & $304.58 \mathrm{~b}$ & $98.50 \mathrm{bc}$ \\
\hline & 4- K-Humat (0.4 $\left.\mathrm{kg} \mathrm{da}^{-1}\right)$ & $12.60 \mathrm{~cd}$ & $2.031 \mathrm{a}$ & $426.15 \mathrm{a}$ & $106.50 \mathrm{ab}$ \\
\hline & 5- K-Humat $\left(0.6 \mathrm{~kg} \mathrm{da}^{-1}\right)$ & $13.50 \mathrm{a}$ & $2.136 \mathrm{a}$ & $438.85 \mathrm{a}$ & $107.00 \mathrm{a}$ \\
\hline & 6- Humik asit (1 lt da-1) & $12.90 \mathrm{bc}$ & $1.992 \mathrm{ab}$ & $406.15 \mathrm{ab}$ & $104.50 \mathrm{ab}$ \\
\hline & 7- Humik asit (2 lt da-1) & $13.20 \mathrm{ab}$ & $2.044 \mathrm{a}$ & $378.23 \mathrm{ab}$ & $98.00 \mathrm{c}$ \\
\hline & 8- Organik toprak düzenleyicisi (150 $\mathrm{kg} \mathrm{da}^{-1}$ ) & $12.20 \mathrm{~d}$ & $2.005 \mathrm{a}$ & $412.60 \mathrm{ab}$ & $103.00 \mathrm{ab}$ \\
\hline & 10- Organik toprak düzenleyicisi (300 $\left.\mathrm{kg} \mathrm{da}^{-1}\right)$ & $13.10 \mathrm{ab}$ & $2.057 \mathrm{a}$ & $395.52 \mathrm{ab}$ & $103.00 \mathrm{ab}$ \\
\hline LSD: & $\mathrm{P}<0.05$ & 0.408 & 0.21715 & 66.672 & 8.0258 \\
\hline
\end{tabular}

\section{Buğday danesi gluten, indeks ve hektolitre değerleri Gluten ve İndeks}

Kimyasal ve organomineral içerikli gübrelerin uygulandı̆̆ parsellerden hasar edilen buğday danesinde belirlenen en düşük gluten değeri kontrol parselinde \%31 olarak belirlenirken, en yüksek gluten değeri ise 6.15 .0 organomineral gübrenin $45 \mathrm{~kg} \mathrm{da}^{-1}$ uygulanmış parselinde $\% 39$ olarak saptanmıştır. Tüm uygulama konularında belirlenen gluten değeri kontrol parselinde belirlenen gluten değerinden yüksek bulunmuştur. Buğdayda gluten bakımından yapılan varyans analizi sonucunda uygulamalar arasındaki farklılıklar istatistiksel olarak önemli bulunmuştur $(\mathrm{p}<0.05)$. Tek başına organik materyallerin uygulandığı parsellerden hasat edilen buğday danesinde yapılan gluten analiz sonucuna göre en düşük gluten değeri kontrol parselinde \%31 olarak belirlenirken, en yüksek gluten değeri ise $0.6 \mathrm{~kg} \mathrm{da}^{-1} \mathrm{~K}-\mathrm{Humat}, 2 \mathrm{lt} \mathrm{da}^{-1} \mathrm{Humik}$ asit ve $300 \mathrm{~kg} \mathrm{da}^{-1}$ Organik toprak düzenleyicisi uygulamasında \%37 olarak saptanmıştır. 
Deneme parsellerinde belirlenen indeks değerlerine bakıldığında ise uygulamalar arasında istatistiksel olarak önemli fark belirlenmemiş ancak tüm uygulamalarda belirlenen indeks değeri literatürlerde verilen sınır indeks değerinden (\%60) daha yüksektir.

Hamurun iskeletini oluşturan gluten, çevreden ve uygulanan azotlu gübreden fazlaca etkilenmektedir. Uygulanan azot ile topraktan alınabilecek azot miktarına bağlı olarak protein ve buna bağlı olarak da gluten miktarı etkilenmektedir. Gluten miktarı artıkça gluten indeksi düşmektedir. Buğdaylarda gluten ve gluten indeksi çeşide, ekolojik şartlara ve tane olum devresindeki hava şartlarına bağlı olarak değişmekte ve unda gluten miktarının \%27'den, gluten indeksinin de \%60'dan daha yüksek olması gerekmektedir (Köksal ve ark., 2000).

\section{Hektolitre}

Kimyasal ve organomineral içerikli gübrelerin uygulandığı parsellerde en düşük hektolitre kontrol parselinde $78.42 \mathrm{~kg} \mathrm{hl}^{-1}$ olarak belirlenirken, en yüksek hektolitre değeri ise $150 \mathrm{~kg} \mathrm{da}^{-1}$ + DAP organik toprak düzenleyicisi uygulanmış parselinde $81.40 \mathrm{~kg} \mathrm{hl}^{-1}$ olarak saptanmıştır. Tüm uygulama konularında belirlenen hektolitre değeri kontrol parselinde belirlenenlerden yüksek bulunmuștur. Buğdayda hektolitre bakımından yapılan varyans analizi sonucunda uygulamalar arasındaki farklılıklar istatistiksel olarak önemli bulunmuştur $(\mathrm{p}<0.05)$. Tek başına organik materyallerin uygulandığı parsellerde en düşük hektolitre kontrol parselinde $78.42 \mathrm{~kg} \mathrm{hl}^{-1}$ olarak belirlenirken, en yüksek hektolitre organik toprak düzenleyicisi (300 $\mathrm{kg} \mathrm{da}{ }^{-1}$ ) uygulamasında $80.60 \mathrm{~kg} \mathrm{hl}^{-1}$ olarak saptanmıștır. Organik materyallerin kimyasal gübreyle karıștırılarak yapılan uygulamalarda hektolitre değerleri, tek bașına organik materyal uygulamalarına göre yüksek bulunmuştur.

Hektolitre 100 lt buğdayın kg olarak ağırlı̆̆ıdır. Un verimi hakkında bilgi verir. 78-81,7 kg hl-1 arası iyi kabul edilir (Kınacl, 1997). Buğday danesinde hektolitre 50-70 ise anormal, 70-73 hafif, 73-77 orta, 77-80 ise ağır (iyi) ve $>80$ ise çok ağır (çok iyi) anlamına gelmektedir. Bu değerlere göre denemede hasat edilen buğday danesi hektolitre değerleri humik asit uygulamaları dışında organik materyal içeren tüm uygulama konularında 80'nin üzerinde bulunmuştur.

Çizelge 6. Farklı uygulama faktörlerinin, zamana ve uygulama faktörlerine bağlı olarak ürün dönemi süresince tanede belirlenen gluten, indeks, hektolitre ve rutubet değerleri

\begin{tabular}{|c|c|c|c|c|}
\hline & & $\begin{array}{c}\text { Hektolitre } \\
\mathrm{kg} \mathrm{hl}^{-1}\end{array}$ & $\begin{array}{c}\text { Gluten } \\
\%\end{array}$ & $\begin{array}{c}\text { İndeks } \\
\%\end{array}$ \\
\hline \multirow{7}{*}{ 焉寻 } & 1 - Gübresiz kontrol & $78.42 \mathrm{e}$ & $31.00 \mathrm{~d}$ & 64.00 öd \\
\hline & 2- Gübreli kontrol (20 kg da-1 DAP) & $79.80 \mathrm{~d}$ & $34.00 \mathrm{c}$ & 61.00 öd \\
\hline & 3- Gübreli kontrol (35 kg da-1 20.20.0) & $80.40 \mathrm{c}$ & $39.00 \mathrm{a}$ & 68.00 öd \\
\hline & 11- Organomineral gübre (7.7.0/ $\left.105 \mathrm{~kg} \mathrm{da}^{-1}\right)$ & $80.70 \mathrm{~b}$ & $37.00 \mathrm{ab}$ & 67.00 öd \\
\hline & 12-Organomineral gübre $\left(10.10 .0 / 70 \mathrm{~kg} \mathrm{da}^{-1}\right)$ & $80.20 \mathrm{c}$ & $37.00 \mathrm{ab}$ & 60.00 öd \\
\hline & 13- Organomineral gübre $\left(6.15 .0 / 45 \mathrm{~kg} \mathrm{da}^{-1}\right)$ & $79.70 \mathrm{~d}$ & $39.00 \mathrm{a}$ & 69.00 öd \\
\hline & 9- Organik toprak düzenleyicisi $\left(150 \mathrm{~kg} \mathrm{da}^{-1}+\mathrm{DAP}\right)$ & $81.40 \mathrm{a}$ & $36.00 \mathrm{bc}$ & 67.00 öd \\
\hline \multicolumn{2}{|c|}{ LSD: $\mathrm{P}<0.05$} & 0.238 & 2.123 & 2.337 \\
\hline \multirow{7}{*}{ 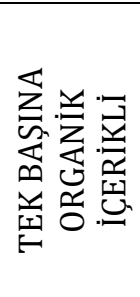 } & 1- Gübresiz kontrol & $78.42 \mathrm{e}$ & $31.00 \mathrm{c}$ & 64.00 öd \\
\hline & 4- K-Humat (0.4 kgda-1) & $81.07 \mathrm{a}$ & $34.00 \mathrm{~b}$ & 62.00 öd \\
\hline & 5- K-Humat (0.6 kgda-1) & $80.20 \mathrm{c}$ & $37.00 \mathrm{a}$ & $65.00 \mathrm{öd}$ \\
\hline & 6- Humik asit (1 lt da-1) & $79.95 \mathrm{~d}$ & $35.00 \mathrm{ab}$ & 62.00 öd \\
\hline & 7- Humik asit (2 lt da-1) & $79.60 \mathrm{e}$ & $37.00 \mathrm{a}$ & 60.00 öd \\
\hline & 8- Organik toprak düzenleyicisi (150 kg da-1) & $80.20 \mathrm{c}$ & $34.00 \mathrm{~b}$ & 61.00 öd \\
\hline & 10- Organik toprak düzenleyicisi $\left(300 \mathrm{~kg} \mathrm{da}^{-1}\right)$ & $80.60 \mathrm{~b}$ & $37.00 \mathrm{a}$ & $62.00 \mathrm{~d}$ öd \\
\hline \multicolumn{2}{|c|}{ LSD: $\mathrm{P}<0.05$} & 0.238 & 2.123 & 2.337 \\
\hline
\end{tabular}

\section{Sonuç}

Yoğun kimyasal gübre kullanılarak tarım yapılan topraklarda konvansiyonel tarımsal üretim tekniklerine bir alternatif olabilecek bu tür organik kaynakların tarımda kullanılması sadece üretim ve kalite artışı değil aynı zamanda da organik ve elde edilmesi daha ucuz doğal kökenli rezervlerin de tarımda kullanılabilme potansiyelini ortaya koyabilecektir. Türkiye'nin önemli doğal kaynaklarından olan linyit, leonardit, gidya gibi toprak düzenleyicilerden elde edilen humik ve fulvik asit içerikleri zengin materyallerin tarımsal üretimde kullanılmasıyla birlikte toprak organik maddesinin artabileceği belirlenmiştir. Elde edilen sonuçlara göre, buğday verim ve kalitesinin, toprak özelliklerinin iyileștirilmesi amacıyla yapılacak uygulama şekillerinin (yapraktan, topraktan, yaprak+topraktan vb.) ve uygulama miktarlarının dikkate alınması gerekir. 
Ülkemizdeki tarımsal üretim ve ekonominin en önemli ürünlerinden ve temel besin kaynağımız olan buğday çeşitleri üzerinde organik toprak düzenleyicilerin etkilerinin ortaya konması verim ve kalitedeki artışı da sağlayabilecek niteliktedir. Ülkemiz genelinde rezerv miktarı bu denli yüksek olan bu toprak düzenleyicilerin bitkisel üretimde kimyasal gübreler ile farklı oranlarda karıştırılarak birlikte kullanımı ile ekonomiye kazandırılması yerinde olacaktır. Bu amaçla, konuyla ilgili olarak ülkemizde yapılan çalışmaların sürdürülebilir toprak verimliği açısından son derece önemli olan organik ve organomineral gübreleri konu alan araştırmaların arttırılması ülkemiz tarımı açısından olukça yararlı olacaktır.

\section{Kaynaklar}

Alagöz Z, Yılmaz E, Öktüren F, 2006. Organik materyal ilavesinin bazı fiziksel ve kimyasal toprak özellikleri üzerine etkileri, Akdeniz Üniversitesi Zirat Fakültesi Dergisi 19(2):245-254.

Atlı A, 1999. Buğday ve ürünleri kalitesi. Orta Anadolu'da Hububat Tarımının Sorunları ve Çözüm Yolları Sempozyumu, 498-506, 8-11 Haziran, Konya.

Barber S, 1995. Soil nutrient bioavailability: A Mechanistic Approach. Wiley, New York.

Bouyoucos GH, 1951. A Recalibration of the hydrometer for making mechanical analysis of soils. Agronomy Journal 43: 434-438.

Bremner JM, 1965. Total nitrogen. In: Black, C.A. (Ed.), Methods of Soil Analysis: Part 2. Chemical and Microbiological Properties. American Society of Agronomy, Madison, WI, pp. 1149-1178.

Doğan Ö, 2007. Afşin Elbistan termik santrali uçucu küllerinden çöktürülmüş kalsiyum karbonat kazanım koşullarının araştırılması. Yüksek Lisans Tezi, Çukurova Üniversitesi Fen Bilimleri Enstitüsü, Adana.

Dönmez E, 2002. Bazı Ekmeklik Buğday (Triticum Aestivum L.) Çeşitlerinde Genotip X Çevre İnteraksiyonları ve Stabilite Analizleri Üzerine Bir Araştırma. Doktora Tezi (Basılmamış), Gaziosmanpaşa Üniversitesi Fen Bilimleri Enstitüsü, Tokat.

Efimov ES, Vertii SA, 1971. Effect of fertilizers on the quality of winter grain under irrigation in the kuban. Field Crop Abstracts 24(1):14.

Engin T, Cöcen İ, 2012. Leonardit ve Humik Maddeler Leonardite and Humic Matters. Journal of Underground Resources. $1(2) ; 13-20$.

Erdal İ, Bozkurt MA, Çimrin K, Karaca S, Sağlam M, 1999. Kireçli bir toprakta yetiştirilen mısır bitkisi (Zea mays L.) gelişimi ve fosfor alımı üzerine humik asit ve fosfor uygulamasının etkisi. Turkish Journal of Agriculture and Forestry 24;663-668

Erol A, 1992. Gidya materyalinin azotun bitkiye yarayışlılı̆̆ına ve bitki gelişimine etkisi. Yüksek Lisans Tezi (Basılmamış), Çukurova Üniversitesi Fen Bilimleri Enstitüsü, Adana.

Gençtan T, Sağlam N, 1987. Ekim zamanı ve ekim sıklığının üç ekmeklik buğday çeşidinde verim ve verim unsurlarına etkisi. Türkiye Tahıl Sempozyumu, 171-183, 6-9 Ekim, Bursa.

Günaydın M, 1999. Yapraktan ve topraktan uygulanan hümik asidin domates ve mısırın gelişimi ile bazı besin maddeleri alımına etkisi. Yüksek Lisans Tezi, Ankara Üniversitesi Fen Bilimleri Enstitüsü, Ankara.

Jackson ML, 1958. Soil Chemical Analysis. Englewood Cliffs, New Jersey.

Jackson ML, 1962. Soil Chemical Analysis. Prentice-Hall. Inc. Eng. Cliffs. N. J., USA.

Kacar B, İnal A, 2008. Bitki analizleri, Cilt 1, Nobel yayını, 892 s, Ankara.

Karabatak İ, 2006. Organik madde uygulamalarının kireçli topraklarda mineral fosfor fraksiyonlarına etkisi. Yüksek Lisans Tezi, Mustafa Kemal Üniversitesi. Fen Bilimleri Enstitüsü, Hatay.

Karaca A, Turgay, C, Tamer N, 2006. Effects of a humic deposit (gyttja) on soil chemical and microbiological properties and heavy metal availability. Biology and Fertility of Soils 42: 585-592.

Kaya M, Atak M, Çiftçi CY, Ünver S, 2005. Çinko ve humik asit uygulamalarının ekmeklik buğday (Triticum aestivum L.)"da verim ve bazı verim öğeleri üzerine etkileri. Süleyman Demirel Üniv. Fen Bilimleri Enstitüsü Dergisi 9(3).

Kınacı G, 1997. Çevre ve Biyotik Faktörlerin Orta Anadoluda Üretilen Bazı Buğday Çeşitlerinin Kalitelerine Etkileri. 2. Un-Bulgur ve Bisküvi Sempozyumu, Bildiri Kitabı, Karaman, s.127-134.

Kırtok Y, Genç İ, Çölkesen, M, 1987. Icarda kökenli bazı arpa çeşitlerinin çukurova koşullarında başlıca tarımsal karakterleri üzerinde araştırmalar. Tübitak Türkiye Tahıl Sempozyumu, 83-90, 6-9 Ekim, Bursa.

Kirven DM, 1986. An industry viewpoint: Horticultural testing-is your language confusing. Proc. of the Sym. Interpretation of extraction and nutrient determination procedures for organic potting substrates, 215- 217.

Koçak Ç, Kürkçü SN, Yılmaz S, 2001. Afşin-Elbistan linyit havzasının değerlendirilmesi ve linyit kaynakları arasındaki yeri. Türkiye 9. Enerji Kongresi Dergisi, 9:28-46

Kolsarıcı Ö, Kaya MD, Day S, İpek A, Uranbey S, 2005. Farklı humik asit dozlarının ayçiçeği'nin (Helianthus annus L.) çıkış ve fide gelişimi üzerine etkileri. Akdeniz Üniversitesi Zirat Fakültesi Dergisi 18(2):15-155.

Köksal H, Sivri D, Özboy Ö, Başman A, Karacan H, 2000. Hububat Laboratuarı El Kitabı. Hacettepe Üni. Mühendislik Fakültesi Yayınları Yayın No:47, Ankara.

Kün E, 1988. Serin iklim tahılları. Ankara Üniversitesi Ziraat Fakültesi Yayınları. No:1032 Ders Kitabı, 299, S. 322, Ankara.

Kün E, 1996. Tahıllar-I (Serin İklim Tahılları). Ankara Üniv. Ziraat Fak. Yayınları, Yayın No:1451, Ankara. 
Lobartini JC, Orioli GA, Tan KH, 1997. Characteristics of soil humic acid fractions seperated by ultrafiltration. Communication in Soil Science and Plant Analyses 28(9-10): 787-796.

Olsen S, Cole C, Watanabe F, Dean L, 1954. Estimation of available phosphorus in soils by extraction with sodium bicarbonate. USDA Circular Nr 939, US Gov. Print. Office, Washington, D.C.

Richards LA, 1954. Diagnosis and improvement of saline and alkali soils. Agricultural hand book 60. U.S. Dept. of Agriculture, Washington D.C., 160 p.

Schnitzer M, Khan SU, 1978. Soil Organic Matter. Academic Pres., New York.

Shirani H, Hajabbasi MA, Afyuni M, Hemmat A, 2002. Effects of farmyard manure and tillage systems on soil physical properties and corn yield in Central Iran. Soil and Tillage Research 68:101-108.

Sözüdoğru S, Kütük C, Yalçın R, Usta S, 1996. Hümik asitin fasulye bitkisinin gelişimi ve besin maddelerini alınımı üzerine etkisi. A.Ü.Z.F. Bilimsel Araştırma ve İncelemeler. No:800 Yayın No:1452, Ankara.

Tamer N, Karaca A, 2006. Gidya ve linyitin toprağın enzim aktiviteleri üzerine etkileri. Selçuk Üniversitesi Ziraat Fakültesi Dergisi 20(38):14-22.

Tamer N, Karaca A, 2011. Organik toprak düzenleyicilerin toprağın enzim aktiviteleri ile buğday verim ve kalitesi üzerine etkileri. Doktora Tezi, Ankara Üniversitesi Fen Bilimleri Enstitüsü, Ankara.

Tamer N, Başalma N, Türkmen C, Namlı A, 2016. Organik toprak düzenleyicilerin toprak parametreleri ve ayçiçeği (Helianthus annuus L.) bitkisinin verim ve verim öğeleri üzerine etkileri. Toprak Bilimi ve Bitki Besleme Dergisi 4 (1) $11-21$.

Tan KH, 1978. Variotions in soil humic compounds, as related to regional and analyitical differences. Soil Science 125(6):351-358.

Tomer NK, Khanna SS, Gupta AF, 1984. Transformation of mixture of missouri rock phosphate and tsp in calcareous soil applied after incubation with organic matter. Hayrana Agriculture University Journal of Research XIV, $324-333$.

Turgay OC, Karaca A, Unver S, Tamer N, 2011. Effects of coal derived humic substances on some soil properties and bread wheat yield. Communications in Soil Science and Plant Analyses 42(9):1050-1070.

U.S. Salinity Laboratory Staff, 1954. Diagnosis and improvement of saline and alkali soils. U.S.D.A. Handbook 60, USA.

Ünal S, 2002. Buğdayda kalitenin önemi ve belirlenmesinde kullanılan yöntemler. Hububat Ürünleri Teknolojisi Kongre ve Sergisi. 25-37, 3-4 Ekim, Gaziantep.

Wang XJ, Wang ZQ, Li SG, 1995. The effect of humic acids on the availability of phosphorus fertilizers in alkaline soils. Soil Use and Management 11(2):99-102.

Yılmaz E, Alagöz Z, 2005. Organik materyal uygulamasının toprağın agregat oluşum ve stabilitesi üzerine etkileri. Akdeniz Üniversitesi Ziraat Fakültesi Dergisi 18(1):131-138.

Yürür N, Tosun O, Eser D, Geçit HH, 1981. Buğdayda anasap verimi ile bazı karakterler arasındaki ilişkiler. Bilimsel Araştırma ve İncelemeler. Ankara Üniversitesi Ziraat Fakültesi Yayınları 755:443. 